\author{
절식시간이 닭고기 품질에 미치는 영향 \\ 최정석* . 박기수* . 이재익** . 어중혁*** . 최양일* \\ 충북대학교 축산학과*, 축산물등급판정소**, 중앙대학교 식품공학과***
}

\title{
Effect of Feed Withdrawal Time on Quality of Broiler Meat
}

\author{
Jung Suck Choi*, Ki Soo Park*, Jae Ik Lee**, Joong Hyuck Auh*** \\ and Yang Il Choi* \\ Department of Animal Science, Chungbuk National University*, Animal Products Grading Service**, \\ Department of Food Science \& Technology, Chungang University***
}

\begin{abstract}
This study was undertaken to investigate the effects of feed withdrawal time (FWT) before transport in farm ( $<2$ hrs, $2 \sim 4$ hrs, $4 \sim 6$ hrs) and total feed withdrawal time (TFWT) before slaughter ( $<8$ hrs, $8 \sim 12$ hrs, $>12$ hrs) on carcass defects, grades and meat quality of broilers. FWT of $2 \sim 4$ hrs before transport in the farm showed lower incidences of dead-on-arrival chicks $(\mathrm{p}<0.05)$ and bruising chicks, and a little higher incidences of 1st or 2nd carcass grade compared to shorter than 2 hrs or $4 \sim 6$ hrs of FWT in the farm. In the meat quality of breast meat, FWT of $2 \sim 4$ hrs in the farm tended to show higher $\mathrm{pH}$ and water holding capacity (WHC), and lower drip loss, cooking loss and shear force values compared to shorter than 2 hrs or $4 \sim 6$ hrs of FWT in the farm. In the total microbial counts of breast meat during 7 days of cooler storage, FWT of $2 \sim 4$ hrs in the farm showed significantly lower value than shorter than 2 hrs of FWT in the farm. In the carcass defects and grades by TFWT before slaughter, TFWT shorter than 8hrs showed lower $(\mathrm{p}<0.05)$ incidences of dead-on-arrival chicks and bruising chicks, and higher $(\mathrm{p}<0.05)$ incidences of 1st carcass grade than TFWT longer than 12 hrs before slaughter. In the meat quality of broiler breast meat, TFWT longer than $12 \mathrm{hrs}$ before slaughter showed lower $(\mathrm{p}<0.05) \mathrm{pH}$ and WHC values, and a little higher drip loss, cooking loss and shear force values compared to TFWT shorter than 8 hrs or $8 \sim 12$ hrs before slaughter. In the total microbial counts of broiler breast meat during 7 days of cooler storage, TFWT longer than 12 hrs before slaughter tended to show higher value than TFWT shorter than 8 hrs or $8 \sim 12$ hrs before slaughter. As a result, $2 \sim 4$ hrs of feed withdrawal time before transport in the farm and total feed withdrawal time shorter than 8 hrs or $8 \sim 12 \mathrm{hrs}$ before slaughter could be recommended for the production of high quality broiler meat.
\end{abstract}

(Key words : Feed withdrawal, Carcass defects, Carcass grades, Broiler meat quality)

$$
\text { I. 서 론 }
$$

우리나라의 양계산업은 국민들의 소득수준 향상과 함께 쇠고기 및 돼지고기에 비해 가격 경쟁력 및 영양학적 우수성으로 닭고기의 소비
수준이 증가되는 추세이나, 소비자의 질적 요 구와 건강에 대한 관심으로 닭고기의 품질, 위 생과 안전성이 중요한 문제로 대두되고 있다. 시장 개방에 따른 수입 축산물과의 경쟁으로 양계산업 분야도 많은 어려움에 봉착하고 있으

Corresponding author: Yang Il Choi, Department of Animal Science, Chungbuk National University, Cheongju 361-763, Korea

Tel : +82-43-261-2550, Fax : +82-43-273-2240, E-mail : yangilchoi@chungbuk.ac.kr 
며, 국내산 닭고기의 가격 진폭이 심하고 유통 구조가 불안정하여 국내 양계산업의 안정화에 많은 노력이 필요한 실정이다. 양계산업의 경 쟁력은 양계농가의 사육기술 개발 및 생산성 향상은 물론, 출하, 도계 및 유통 과정 중에 과 학적인 적정조건을 수립하여 수입 닭고기에 경 쟁력을 갖는 위생적이며 고품질의 닭고기 생산 으로 소비자의 욕구를 충족시킬 수 있는 것이 매우 시급하다고 할 수 있다. 농장출하 및 상 하차관리에 있어서도 도계시 닭의 장 내용물에 의해 발생할 수 있는 도체의 오염을 예방하기 위해 도계전에 절식이 충분히 이루어져야 하는 데 여기에 대한 정확한 기준이 확립되어있지 않고 있으며, 상하차시에도 대부분의 도계장에 서 차량에 고정된 어리장 (fixed crate)에 던져 넣는 방식을 택함으로써 홍계, 멍계, 골절계 등 의 발생비율이 특히 높아 닭의 품질을 저하시 키는 경우가 많이 발생한다 (김 등, 2004).

농장 출하전 육계는 절식과정을 거치는데 만 약, 절식이 제대로 이루어지지 않으면 운송 중 포만감에 따른 피로축적이 심해져, 도계시 내 장적출을 어렵게 할 뿐만 아니라 파열되기도 쉬워 분변에 의한 도체의 오염이 일어날 수 있 다 (Hargis 등, 1995). 육계의 소화기관을 비우기 위해서는 출하전 4시간 이상의 절식이 필요하 며, 그 다음 상차시간 2 3시간, 수송 1 2시간, 그리고 계류 1 시간을 포함시키면 실제 도계전 8 10시간의 절식시간을 가지게 된다. 이보다 절식시간이 길어지면 계육생산성이 떨어진다 (Veerkamp, 1986; Warriss 등, 1990). 육계의 절 식이 시작되고 3시간 이후에는 혈액내 glucose 의 수준을 유지하기 위해 간에 저장되어 있는 glycogen의 분해가 시작되고, 이에 따라 근육 내 $\mathrm{pH}$ 가 감소한다(Warriss 등, 1988; Wal 등, 1999). 그러나 여러 연구들에 의하면 8시간 정 도의 절식은 절식을 시키지 않은 육계에 비해 혈액내 glucose 수준, $\mathrm{pH}$ 등에 유의적인 차이를 나타내지 않는다(Warriss 등, 1993). 오히려 육 계의 절식이 도계 후 근육내 glucose 수준, $\mathrm{pH}$, 전단력 등에 미치는 영향은 절식자체보다는 외 부의 다른 요인들로서 수송, 투쟁, 기절방법 등 이 더 큰 영향을 미치는 것으로 보고되었다
(Warriss 등, 1988; Fletcher, 1991; Ali 등, 1999). 절식과 절수는 모두 육계에게 스트레스를 주 나, 너무 장시간의 절식과 절수만 피한다면 큰 문제는 되지 않는 것으로 보고된 바 있다 (Nicol and Scott, 1990).

육계에게 스트레스를 주는 도계전 요인들은 출하전 절식과 절수 이외에도, 수송중의 외부 환경온도, 진동, 소음, 수송시간 등이 포함된다 (Nicol and Scott, 1990; Mitchell 등, 1997). 육계 는 1 시간에서 3 시간의 수송 후에 수송 스트레 스에 의해서 corticosterone 호르몬 수준이 높아 지는 것으로 보고되었다(Knowles and Broom, 1990). 그러나 도계전 요인들이 육계의 최종 육 질에 미치는 영향들은 연구결과들에서 일치하 는 경향을 보이지 않는다 (Mielnik and Kolstad, 1991; Warriss 등, 1993, 1999; Smith, 2002).

본 연구는 국내의 육계농장에서 출하전 절식 시간이 육계의 육질에 미치는 영향을 조사하여 최적조건 구명의 기초 자료로 활용하고자 실시 하였다.

\section{․ 재료 및 방법}

\section{1. 공시재료}

충북 관내의 C계열화업체의 협조로 30 개소 계열화 사양농가 $(80 \mathrm{~km}$ 이내 수송거리, 차당수 수 평균 2,600수, 평사, 35일 평균 사육일령)에 서 출하된 육계를 대상으로 절식시간을 달리하 여 HACCP 인증 도계장에서 사계 및 멍계의 발생율을 조사하였으며, 관행적인 방법에 따라 도계된 통닭을 무작위로 100수씩을 선정하여 닭고기 등급판정기준 (축산물등급판정소, 2003) 에 의해 등급판정과 하자발생을 조사하였다. 이때 절식시간은 농장에서 출하전 2시간 이내, 2 4시간과 4 6시간으로 나누었으며, 도계전 총 절식시간은 8 시간 이내, 8 12시간과 12 시간 이 상으로 구분하였다. 그 외 각 사양농가의 등급 판정된 통닭 중 20수씩을 냉장상태로 실험실로 신속하게 운반하여 발골 후 계흉육 (breast meat) 을 시험재료로 아래 항목들을 분석하였다. 


\section{2. 실험방법}

(1) 일반성분 분석

대상 시료육의 일반 성분인 수분, 지방 및 회분 (\%)은 AOAC 방법 (1995)에 따라 건조법, soxhlet법 및 회화법을 사용하여 분석하였다.

(2) $\mathrm{pH}$, 육즙 손실, 보수력 및 가열 감량 $\mathrm{pH}$ 는 시료 $10 \mathrm{~g}$ 에 증류수 $90 \mathrm{ml}$ 를 가하여 1 분 간 균질시킨 후 digital $\mathrm{pH}$ meter (Mettler Delta 340, Mettler-Toledo, Ltd., UK)로 측정하였다. 육 즙손실 (drip loss)은 시료육을 $1 \mathrm{~cm}$ 의 두께로 절 단하여 시료무게를 측정한 후, 진공 포장하여 $4^{\circ} \mathrm{C}$ 에서 24 시간 저장 후, 무게 변화를 측정하 여 백분율 (\%)로 산출하였다. 보수력 (water holding capacity)은 시료 $5 \mathrm{~g} \pm 0.05 \mathrm{~g}$ 을 원심분리용관의 상부 필터에 넣고 수조 $\left(70^{\circ} \mathrm{C}\right)$ 에서 5 분간 가열 한 후, $2,000 \mathrm{rpm}$ 에서 10 분간 원심분리시켜 남 은 시료무게를 가열전 무게로 나눈 백분율(\%) 로 표시하였다(Kristensen and Purslow, 2001). 가열감량 (cooking loss)은 두께 $1 \mathrm{~cm}$ 의 시료육을 유리병에 옮긴 후 밀봉을 하여, $70^{\circ} \mathrm{C}$ 에서 40 분 간 가열한 후의 감량을 가열전 무게로 나눈 백 분율 $(\%)$ 로 표시하였다.

\section{(3) 전단력 및 육색 분석}

전단력 (shear force)은 $70^{\circ} \mathrm{C}$ 에서 40 분간 가열 한 시료를 $1 \times 1 \times 2 \mathrm{~cm}^{3}$ 의 크기로 채취한 후 Sun Rheometer (Compac-100, Sun Scientific Co. $\mathrm{Ltd}$, Japan)로 측정하였다. 사용한 adapter는 접 촉면적이 $0.79 \mathrm{~cm}^{2}$ 인 circle 형태의 것을 사용하 여, table speed는 $60 \mathrm{~mm} / \mathrm{min}$ 으로 조정하여 측정 하였다. 시료육의 표면육색은 백색판 $\left(\mathrm{L}^{*}, 89.39\right.$; $\left.\mathrm{a}^{*}, 0.13 ; \mathrm{b}^{*},-0.51\right)$ 으로 표준화시킨 SpectroColormeter (Model JX-777, Color Techno. System. Co., Japan)로 측정하였으며, 이때 광원은 백색 형광등 (D65)을 사용하여 CIE (Commision Internationale de Leclairage)의 $\mathrm{L}^{*}$ (명도), $\mathrm{a}^{*}$ (적색도), $\mathrm{b}^{*}$ (황색도) 값으로 나타내었다.

(4) 저장성조사

저장성은 7 일간의 냉장 $\left(4^{\circ} \mathrm{C}\right)$ 저장기간 중에
지방산패도, 휘발성염기태질소와 총미생물수를 $0,4,7$ 일마다 조사하였다. 지방산패도는 Witte 등 (1970)의 추출방법에 따라 TBA (2-thiobarbituric acid) 수치로 측정하였으며, 휘발성염기태 질소 (volatile basic nitrogen, $\mathrm{VBN}$ )는 Conway 미 량확산법으로 측정하였다 (高坂, 1975). 총미생 물수는 희석한 시료를 standard plate count 배지 에 접종하여 $36^{\circ} \mathrm{C}$ 에서 48 시간 배양시킨 후 측 정하였다 (APHA, 1985). TBA 수치는 시료 $1,000 \mathrm{~g}$ 당 $\mathrm{mg}$ malonaldehyde 양으로 표시하였 고, 휘발성염기태질소 $(\mathrm{VBN})$ 는 $\mathrm{mg} \%$ 로, 그리고 총미생물수는 시료 $1 \mathrm{~g}$ 당 미생물수 (CFU; colony foming unit)로 표시하였다.

\section{3. 통계분석}

본 실험의 통계처리는 SAS (Statistical analysis system; The SAS system Release 9.01, 2002)의 General Liner Model를 이용하여 분석하였고, Duncan's multiple range test를 사용하여 유의성 $5 \%$ 수준에서 검증하였다.

\section{II. 결과 및 고찰}

\section{1. 출하전 농장에서의 절식시간에 따른 닭고 기 육질특성}

출하전 육계농장에서의 절식시간이 육계의 사계와 멍계발생율과 도계등급에 미치는 영향 은 Table 1에서 보는 바와 같다. 2 4시간 절식 의 경우 2시간 이내 절식이나 4 6시간 절식에 비해 사계발생율이 유의적으로 낮았으며 $(\mathrm{p}<$ $0.05)$, 멍계발생율도 다소 낮은 경향이었다. 그 외 도계등급결과에서도 1 등급과 2 등급 판정율 이 다소 높았으며, 3 등급 판정율 $(\mathrm{p}<0.05)$ 과 등 외판정비율도 다소 낮았다.

출하전 절식시간이 통닭의 하자발생율에 미 치는 영향에서도(Table 2) 2 4시간 절식의 경 우 외관, 잔모, 변색 및 골절발생비율이 낮은 경향이었으나 유의적 차이를 보이지는 못했다.

출하전 육계농장에서의 절식시간이 육계 가 슴육의 일반성분에 미치는 영향은 Table 3에서 
Table 1. Effect of feed withdrawal time in farm on the incidence of death, bruising and carcass grades

\begin{tabular}{lcccc}
\hline \multicolumn{1}{c}{ Items } & $<2 \mathrm{hr}$ & $2 \sim 4 \mathrm{hr}$ & $4 \sim 6 \mathrm{hr}$ \\
\hline \hline Death (\%) & & $0.87 \pm 0.21^{\mathrm{a}}$ & $0.47 \pm 0.17^{\mathrm{b}}$ & $0.74 \pm 0.27^{\mathrm{a}}$ \\
Bruising (\%) & 1 & $5.55 \pm 0.34$ & $0.42 \pm 0.23$ & $0.86 \pm 0.41$ \\
\hline \multirow{3}{*}{ Carcass } & 2 & $27.6 \pm 5.3$ & $56.8 \pm 7.6$ & $54.3 \pm 8.7$ \\
grade (\%) & 3 & $15.2 \pm 4.3^{\mathrm{a}}$ & $32.5 \pm 10.5$ & $29.7 \pm 9.5$ \\
& Below & $4.5 \pm 2.2$ & $7.5 \pm 2.3^{\mathrm{b}}$ & $11.3 \pm 5.2^{\mathrm{ab}}$ \\
\hline
\end{tabular}

a,b Different letters in a row indicate significant difference $(\mathrm{p}<0.05)$.

Table 2. Effect of feed withdrawal time in farm on appearance, pin feather, discoloration and bone fracture of whole carcasses

\begin{tabular}{cccc}
\hline Carcass defects (\%) & $<2 \mathrm{hr}$ & $2 \sim 4 \mathrm{hr}$ & $4 \sim 6 \mathrm{hr}$ \\
\hline \hline Appearance & $7.7 \pm 5.9$ & $7.3 \pm 4.5$ & $8.0 \pm 6.5$ \\
Pin feather & $7.8 \pm 5.7$ & $6.8 \pm 5.3$ & $8.6 \pm 5.8$ \\
Discoloration & $8.2 \pm 7.3$ & $6.0 \pm 3.4$ & $7.5 \pm 4.0$ \\
Bone fracture & $1.9 \pm 0.8$ & $1.2 \pm 0.7$ & $1.8 \pm 0.9$ \\
\hline
\end{tabular}

Table 3. Effect of feed withdrawal time in farm on chemical composition of breast meat

\begin{tabular}{cccc}
\hline Composition (\%) & $<2 \mathrm{hr}$ & $2 \sim 4 \mathrm{hr}$ & \multicolumn{1}{c}{$4 \sim 6 \mathrm{hr}$} \\
\hline \hline Moisture & $76.2 \pm 0.2$ & $76.7 \pm 1.3$ & $76.1 \pm 2.4$ \\
Fat & $0.8 \pm 0.2$ & $0.8 \pm 0.1$ & $0.9 \pm 0.2$ \\
Ash & $1.4 \pm 0.1$ & $1.2 \pm 0.1$ & $1.3 \pm 0.2$ \\
\hline
\end{tabular}

보는 바와 같다. 일반성분에서 수분은 76.1 $76.7 \%$, 지방은 $0.8 \sim 0.9 \%$, 회분 $1.2 \sim 1.4 \%$ 를 나타 내어 절식시간에 따른 유의적인 영향은 나타나 지 않았다. 출하전 절식시간에 따른 가슴육의 육질특성에서는 (Table 4) 2 4시간 절식의 경우 2시간 이내 절식이나 4 6시간 절식에 비해 가 슴육의 $\mathrm{pH}$ 와 보수력은 높고, 가열감량과 전단 력은 낮은 경향이었으나 유의적인 차이는 없었
다. 그러나 육즙손실에서는 2 4시간 절식의 경 우 2시간 이내 절식에 비해 유의적으로 낮은 $(\mathrm{p}<0.05)$ 손실을 나타내었다. 육색에서도 2 시간 이내 절식에서 명도와 황색도가 높은 경향이었 으나 절식시간에 따른 유의적인 차이는 없었다.

출하전 절식시간이 육계 가슴육의 저장특성 에 미치는 영향은 Table 5에서 보는 바와 같다. 7일간 냉장저장기간 중의 총미생물수에서는 냉

Table 4. Effect of feed withdrawal time in farm on the meat quality of breast meat

\begin{tabular}{|c|c|c|c|c|}
\hline \multicolumn{2}{|c|}{ Items } & $<2 \mathrm{hr}$ & $2 \sim 4 \mathrm{hr}$ & $4 \sim 6 \mathrm{hr}$ \\
\hline \multicolumn{2}{|c|}{$\mathrm{pH}$} & $5.65 \pm 0.06$ & $5.81 \pm 0.26$ & $5.77 \pm \quad 0.12$ \\
\hline \multicolumn{2}{|c|}{ Drip loss (\%) } & $2.34 \pm \quad 0.27^{\mathrm{a}}$ & $1.95 \pm 0.24^{\mathrm{b}}$ & $2.19 \pm 0.35^{\mathrm{ab}}$ \\
\hline \multicolumn{2}{|c|}{ Cooking loss (\%) } & $18.89 \pm 2.08$ & $16.53 \pm 1.97$ & $17.63 \pm \quad 2.46$ \\
\hline \multicolumn{2}{|c|}{ Shear force (g) } & $1,348.4 \pm 270.5$ & $1,178.0 \pm 192.3$ & 1,323.6 \pm 203.9 \\
\hline \multicolumn{2}{|c|}{ WHC (\%) } & $60.9 \pm 4.2$ & $66.9 \pm 3.4$ & $65.3 \pm 3.1$ \\
\hline \multirow{3}{*}{ CIE } & $\mathrm{L}^{*}$ & $52.1 \pm 2.1$ & $50.6 \pm 2.0$ & $50.3 \pm 4.3$ \\
\hline & $a^{*}$ & $3.1 \pm 0.2$ & $3.5 \pm 0.5$ & $3.2 \pm 1.0$ \\
\hline & $b^{*}$ & $9.6 \pm 1.1$ & $8.9 \pm 1.7$ & $8.7 \pm 1.4$ \\
\hline
\end{tabular}

1) WHC, Water holding capacity.

a,b Different letters in a row indicate significant difference $(\mathrm{p}<0.05)$. 
Table 5. Effect of feed withdrawal time in farm on storage characteristics of breast meat during 7 days of cooler storage

\begin{tabular}{ccccc}
\hline Items & & $<2 \mathrm{hr}$ & $2 \sim 4 \mathrm{hr}$ & $4 \sim 6 \mathrm{hr}$ \\
\hline \hline \multirow{2}{*}{ Microbial counts } & 0 day & $4.21 \pm 0.73$ & $3.57 \pm 0.74$ & $3.79 \pm 0.53$ \\
$(\mathrm{Log}$ CFU/g) & 4 day & $4.26 \pm 0.16^{\mathrm{a}}$ & $3.62 \pm 0.35^{\mathrm{b}}$ & $3.74 \pm 0.44^{\mathrm{b}}$ \\
& 7 day & $4.61 \pm 1.08$ & $3.85 \pm 0.21$ & $3.98 \pm 1.10$ \\
\hline \multirow{2}{*}{$\mathrm{TBA}^{1)}$} & 0 day & $0.13 \pm 0.08$ & $0.09 \pm 0.03$ & $0.11 \pm 0.04$ \\
& 4 day & $0.18 \pm 0.11$ & $0.13 \pm 0.07$ & $0.16 \pm 0.08$ \\
& 7 day & $0.23 \pm 0.13$ & $0.15 \pm 0.02$ & $0.17 \pm 0.06$ \\
\hline \multirow{2}{*}{$\mathrm{VBN}^{2)}$} & 0 day & $17.89 \pm 1.71$ & $16.66 \pm 2.05$ & $17.20 \pm 2.33$ \\
$\left(\mathrm{mg}^{1)}\right.$ & 4 day & $18.91 \pm 3.05$ & $18.22 \pm 3.95$ & $17.77 \pm 3.17$ \\
& 7 day & $18.56 \pm 2.91$ & $18.45 \pm 4.30$ & $18.21 \pm 2.97$ \\
\hline
\end{tabular}

1) TBA, 2-thiobarbituric acid; mg malonaldehyde/1,000g.

2) VBN, volatile basic nitrogen.

a,b Different letters in a row indicate significant difference $(\mathrm{p}<0.05)$.

장 4일에서 2 4시간 절식이 다소 낮은 수치를 보였으며, 반면에 2시간이내의 절식에서 가장 높은 수치를 보였다 $(\mathrm{p}<0.05)$. 지방산패도와 휘 발성염기태질소 $(\mathrm{VBN})$ 에서도 2 4시간 절식이 저장기간 중 다소 낮은 경향이었고, 반면에 2 시간 이내의 절식에서 다소 높은 경향이었다. 농장에서 출하전 절식시간이 2시간 이내인 육 계의 가슴육에서 저장특성이 열악하게 나타나 는 이러한 결과는 농장 출하전 절식이 제대로 이뤄지지 않으면 운송 중 포만감에 따른 피로 축적이 심하며, 도계시 내장적출을 어렵게 할 뿐만 아니라 파열하기도 쉬워 분변에 의한 도 체의 오염이 높아진다는 보고와 동일한 경향을 보이고 있다 (Hargis 등, 1995).

\section{2. 도계전 총 절식시간에 따른 닭고기 육질 특성}

도계전 육계의 총 절식시간이 육계의 사계와 멍계발생율과 도계등급에 미치는 영향은 Table 6 에서 보는 바와 같다. 8시간 이내의 총 절식 시간은 12 시간 이상의 총 절식시간에 비해 유 의적으로 낮은 $(\mathrm{p}<0.05)$ 사계 및 멍계발생율을 나타냈으며, 도계등급 결과에서도 유의적으로 높은 $(\mathrm{p}<0.05) 1$ 등급 발생율을 보였으며, 3 등급 발생율과 등외판정비율도 낮은 경향이었다. 그 러나 8시간 이내의 총 절식시간과 8 12시간 총 절식시간 사이에서는 유의적인 차이가 없었으 며, 모든 항목에서 유사한 경향이었다. 도계전 총 절식시간이 통닭의 하자발생율에 미치는 영 향에서도 (Table 7) 8시간 이내의 총 절식시간 의 경우 잔모, 변색 및 골절발생비율이 다소 낮은 경향이었으며, 12 시간 이상의 총 절식시 간이 다소 열악한 결과를 나타냈다.

도계전 육계의 총 절식시간이 육계 가슴육의

Table 6. Effect of total feed withdrawal time before slaughter on the incidence of death, bruising and carcass grades

\begin{tabular}{ccccc}
\hline Items & $<8 \mathrm{hr}$ & $8 \sim 12 \mathrm{hr}$ & $>12 \mathrm{hr}$ \\
\hline \hline Death (\%) & & $0.47 \pm 0.21^{\mathrm{b}}$ & $0.53 \pm 0.19^{\mathrm{ab}}$ & $0.84 \pm 0.27^{\mathrm{a}}$ \\
Bruising (\%) & & $0.55 \pm 0.21^{\mathrm{b}}$ & $0.77 \pm 0.31^{\mathrm{b}}$ & $1.68 \pm 0.44^{\mathrm{a}}$ \\
\hline & 1 & $67.3 \pm 1.5^{\mathrm{a}}$ & $65.8 \pm 4.4^{\mathrm{a}}$ & $56.4 \pm 4.8^{\mathrm{b}}$ \\
Carcass grade (\%) & 2 & $24.7 \pm 5.1$ & $23.5 \pm 3.8$ & $30.5 \pm 6.9$ \\
& 3 & $5.3 \pm 1.2$ & $6.1 \pm 3.2$ & $7.4 \pm 4.5$ \\
& Below & $2.7 \pm 1.8$ & $4.6 \pm 1.6$ & $5.7 \pm 2.7$ \\
\hline
\end{tabular}

a,b Different letters in a row indicate significant difference $(\mathrm{p}<0.05)$. 
Table 7. Effect of total feed withdrawal time before slaughter on appearance, pin feather, discoloration and bone fracture of whole carcasses

\begin{tabular}{cccc}
\hline Carcass defects (\%) & $<8 \mathrm{hr}$ & $8 \sim 12 \mathrm{hr}$ & $>12 \mathrm{hr}$ \\
\hline \hline Appearance & $5.3 \pm 3.1$ & $5.0 \pm 3.5$ & $7.3 \pm 5.2$ \\
Pin feather & $6.8 \pm 4.9$ & $7.6 \pm 5.3$ & $7.7 \pm 4.0$ \\
Discoloration & $7.3 \pm 4.6$ & $7.5 \pm 3.0$ & $9.5 \pm 5.8$ \\
Bone fracture & $1.2 \pm 0.5$ & $1.4 \pm 0.7$ & $1.7 \pm 1.0$ \\
\hline
\end{tabular}

Table 8. Effect of total feed withdrawal time before slaughter on chemical composition of breast meat

\begin{tabular}{crrr}
\hline Composition (\%) & \multicolumn{1}{c}{$<8 \mathrm{hr}$} & $8 \sim 12 \mathrm{hr}$ & $>12 \mathrm{hr}$ \\
\hline \hline Moisture & $75.2 \pm 0.4$ & $76.1 \pm 1.4$ & $74.6 \pm 1.7$ \\
Fat & $0.9 \pm 0.1$ & $0.8 \pm 0.2$ & $0.8 \pm 0.2$ \\
Ash & $1.4 \pm 0.1$ & $1.3 \pm 0.1$ & $1.3 \pm 0.2$ \\
\hline
\end{tabular}

Table 9. Effect of total feed withdrawal time before slaughter on the meat quality characteristics of breast meat

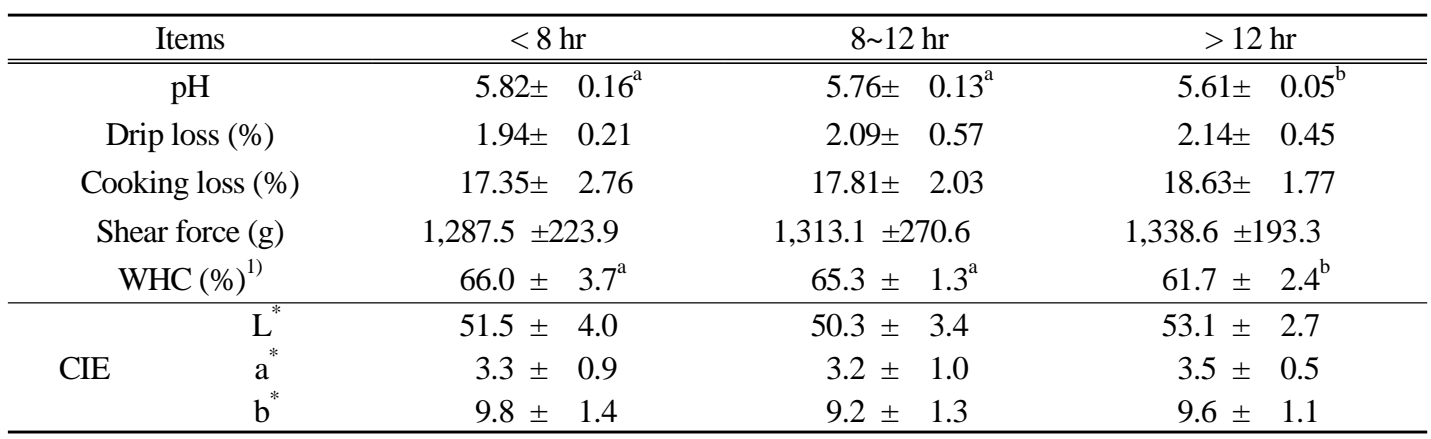

1) WHC, Water holding capacity.

a,b Different letters in a row indicate significant difference $(\mathrm{p}<0.05)$.

Table 10. Effect of total feed withdrawal time before slaughter on storage characteristics of breast meat during 7 days of cooler storage

\begin{tabular}{clccc}
\hline Items & & $<8 \mathrm{hr}$ & $8 \sim 12 \mathrm{hr}$ & $>12 \mathrm{hr}$ \\
\hline \hline Microbial & 0 day & $3.82 \pm 0.41$ & $3.96 \pm 0.91$ & $4.12 \pm 0.83$ \\
counts & 4 day & $3.97 \pm 0.81$ & $3.96 \pm 0.87$ & $4.28 \pm 1.01$ \\
$($ Log CFU/g) & 7 day & $4.04 \pm 0.94$ & $4.18 \pm 0.95$ & $4.60 \pm 0.74$ \\
\hline & 0 day & $0.09 \pm 0.03$ & $0.11 \pm 0.09$ & $0.12 \pm 0.08$ \\
TBA $^{1)}$ & 4 day & $0.12 \pm 0.08$ & $0.14 \pm 0.06$ & $0.16 \pm 0.11$ \\
& 7 day & $0.12 \pm 0.04$ & $0.16 \pm 0.08$ & $0.21 \pm 0.10$ \\
\hline \multirow{2}{*}{$\mathrm{VBN}^{2)}$} & 0 day & $17.06 \pm 2.05$ & $17.19 \pm 2.03$ & $17.79 \pm 1.71$ \\
$\left(\mathrm{mg}^{2}\right)$ & 4 day & $18.22 \pm 2.95$ & $17.67 \pm 2.17$ & $18.19 \pm 2.05$ \\
& 7 day & $18.34 \pm 4.03$ & $18.29 \pm 1.97$ & $18.65 \pm 1.28$ \\
\hline
\end{tabular}

1) TBA, 2-thiobarbituric acid; mg malonaldehyde/1,000g.

2) VBN, volatile basic nitrogen. 
일반성분에 미치는 영향은 Table 8에서 보는 바와 같다. 일반성분에서 수분은 $74.6 \sim 76.1 \%$, 지방은 $0.8 \sim 0.9 \%$, 회분은 $1.3 \sim 1.4 \%$ 를 나타내어 총 절식시간은 일반성분에 유의적인 영향을 나 타내지 않았다. 도계전 육계의 총 절식시간에 따른 가슴육의 육질특성에서는 (Table 9) 8시간 이내의 총 절식시간과 8 12시간 총 절식시간의 경우 12 시간 이상의 총 절식시간에 비해 가슴 육의 $\mathrm{pH}$ 와 보수력이 유의적으로 높았으며 $(\mathrm{p}<$ $0.05)$, 육즙손실, 가열감량과 전단력은 낮은 경 향을 보였다. 이는 육계의 소화기관을 비우기 위해서는 농장에서 출하전 4시간 정도의 절식 이 필요하고, 상차, 수송 및 계류를 포함하여 8 10시간 정도의 총 절식시간이 적합하며, 이 보다 절식시간이 길어지면 수송 등의 스트레스 로 육질저하나 도체품질 등의 계육생산성이 떨 어진다는 보고와 일치하는 경향을 보였다 (Veerkamp, 1986; Warriss 등, 1990). 육색의 경 우 12 시간 이상의 총 절식시간에서 명도 $\left(\mathrm{L}^{*}\right)$ 와 적색도 $\left(a^{*}\right)$ 가 다소 높은 경향을 보였으나, 처리 구간에 유의적인 차이는 없었다. 이러한 결과 는 8시간의 절식이 육계 가슴육의 명도를 유의 적으로 증가시키고, 적색도는 유의적으로 감소 시켰다는 Smith 등(2001)의 보고와는 다소 다 른 경향이었다. 도계전 육계의 총 절식시간이 육계 가슴육의 저장특성에 미치는 영향은 Table 10에서 보는 바와 같다. 7일간의 냉장저 장기간 중의 총 미생물수에서는 12 시간 이상의 총 절식시간이 다소 높은 수치를 보였으며, 반 면에 8시간 이내의 총 절식시간이 낮은 경향을 나타냈다. 그 외 지방산패도와 휘발성염기태질 소에서는 처리구간에 유사한 경향이었다.

\section{IV. 요 약}

본 연구는 육계농장에서 출하전 절식시간 (2 시간 이내, 2 4시간, 4 6시간)과 도계전 총 절 식시간 (8시간 이내, 8 12시간, 12 시간 이상)이 통닭의 하자발생, 도계등급과 육질에 미치는 영향을 조사하기 위해 수행하였다. 출하전 농 장에서의 절식시간은 2 4시간의 경우 2시간 이 내나 4 6시간 절식에 비해 사계 $(\mathrm{p}<0.05)$ 와 멍
계의 발생율이 낮았으며, 도계등급결과에서도 1 등급과 2 등급 판정율이 다소 높았다. 출하전 농장에서의 절식시간이 가슴육의 육질에 미치 는 영향에서는 2 4시간 절식의 경우 2시간 이 내나 4 6시간 절식에 비해 $\mathrm{pH}$ 와 보수력이 다 소 높았고, 육즙손실, 가열감량과 전단력이 다 소 낮았다. 출하전 절식시간이 가슴육의 7일간 냉장저장기간 중에 총미생물수에 미치는 영향 에서 냉장 4일에서 2 4시간 절식이 2시간 이내 의 절식에 비해 유의적으로 낮은 수치를 나타 냈다. 도계전 육계의 총 절식시간에서 8시간 이내의 총 절식시간은 12 시간 이상의 총 절식 시간에 비해 사계와 멍계의 발생율이 낮았으며 $(\mathrm{p}<0.05)$, 도계등급 결과에서도 1 등급 판정율이 유의적으로 높았다. 도계전 육계의 총 절식시 간이 가슴육의 육질에 미치는 영향에서는 12 시 간 이상의 총 절식시간이 8시간 이내나 8 12시 간의 총 절식시간에 비해 $\mathrm{pH}$ 와 보수력이 낮았 고 $(\mathrm{p}<0.05)$, 육즙손실, 가열감량과 전단력이 다 소 높은 경향을 보였다. 도계전 총 절식시간이 가슴육의 7일간 냉장저장중에 총미생물수에 미 치는 영향에서 12 시간 이상의 총 절식시간이 8 시간 이내나 8 12시간의 총 절식시간에 비해 다소 높은 경향을 나타내었다. 이상의 결과에 서 출하전 육계 농장에서의 절식시간은 2 4시 간이, 도계전 총 절식시간은 8시간 이내 또는 8 12시간의 절식시간이 닭고기 최종 품질에 가 장 좋은 영향을 나타내었다.

$$
\mathrm{V} \text {. 사 사 }
$$

이 논문은 2006년도 충북대학교 학술연구지 원사업의 연구비지원에 의하여 연구되었음.

\section{VI. 인 용 문 헌}

1. Ali, A. S. A., Harrison, A. P. and Jensen, F. 1999. Effects of some ante-mortem stressors on peri-mortem and post-portom biochemical changes tenderness in broiler breast muscle: A review. World's Poult. Sci. J. 55:403-414.

2. AOAC. 1995. Official Methods of Analysis, 16th 
ed. Association of Official Analytical Chemists, Washington, D.C., U.S.A. Vol. II. Chap. 39.

3. APHA. 1985. Standard methods for the examination of water and wastewater, 16th ed. American Pubic Health Association, Washington, D.C., U.S.A.

4. Fletcher, D. 1991. Ante mortem factors related to meat quality. In Proceeding of the 10th European Symposium of Poultry Meat, T. G. Uijttenboogaart, and C. H. Veerkamp (Eds.), Spelderholt Centre for Poultry Research and Information Services, Beekbergen, Netherlands. pp. 11-19.

5. Hargis, B. M., Caldwell, D. J., Brewer, R. L., Corrier, D. E. and Deloach, J. R. 1995. Evaluation of the chicken crop as a source of Salmonella contamination for broiler carcasses. Poult. Sci. 74:1548-1552.

6. Knowles, T. G. and Broom, D. M. 1990. The handling and transport of broilers and spent hens. Appl. Anim. Behav. Sci. 28:75-91.

7. Kristensen, L. and Purslow, P. P. 2001. The effect of ageing on the water-holding capacity of pork: role of cytoskeletal proteins. Meat Sci. 58: 17-23.

8. Mielnik, M. and Kolstad, N. 1991. The influence of transportation time on the quality of broiler meat. Norwegian J. Agric. Sci. 5:245-251.

9. Mitchell, A. M., Carlisle, A. J., Hunter, R. R. and Kettlewell, P. J. 1997. Welfare of Broilers during transportation: Cold stress in winter-causes and broilers solution, In Proceedings of the 5th European Symposium on Poultry Welfare, P. Koene, H. J. Blokhuis (Eds.), Wageningen Agricultural University, Wageningen, Netherlands. pp. 49-52.

10. Nicol, C. J. and Scott, G. B. 1990. Pre-slaughter handling and transport of broiler chickens. Appl. Anim. Behav. Sci. 28:57-73.

11. SAS. 2002. The SAS System Release 9.1, SAS Institute Inc., Cary, NC.

12. Smith, D. P., Lyon, C. E. and Lyon, B. G. 2002. The effect of age, dietary carbohydrate source, and feed withdrawal on broiler breast fillet color. Poult. Sci. 81:1584-1588.

13. Veerkamp, C. H. 1986. Fasting and yields of broilers. Poult. Sci. 65:1299-1304.

14. Wal, P. G. van der, Reimert, H. G. M., Goedhart, H. A., Engel, B. and Uijttenboogaart, T. G. 1999. The effect of feed withdrawal on broiler blood glucose and nonesterified fatty acid levels, postmortem liver $\mathrm{pH}$ values, and carcass yield. Poult. Sci. 78:569-573.

15. Warriss, P. D., Bevan, E. A. and Brown, S. N. 1990. Time spent by broiler chickens in transit to processing plants. Vet. Rec. 127:617-619.

16. Warriss, P. D., Kestin, S. C., Brown, S. N. and Bevis, E. A. 1988. Depletion of glycogen reserves in fasting broiler chickens. Br. Poult. Sci. 29:149154.

17. Warriss, P .D., Kestin, S. C., Brown, S. N., Knowles, T. G., Wilkins, L. J., Edwards, H. E., Austin, S. D. and Nicol, C. J. 1993. The depletion of glycogen stores and indices of dehydration in transported broilers. Br. Vet. J. 149:391-398.

18. Warriss, P. D., Knowles, T. G., Brown, S. N., Edwarsd, J. E., Ketlewell, P. J., Mitchell, R. A. and Baxter, C. A. 1999. Effects of lairage time on body temperature and glycogen reserves of broiler chickens held in transport modules. Vet. Rec. 145:218-222.

19. Witte, V. C., Krause, G. F. and Baile, M. E. 1970. A new extraction method for determining 2thiobarbituric acid values of pork and beef during storage. J. Food Sci. 35:582-585.

20. 高坂知久. 1975. 肉製品の 鮮度保持と 測定. 食 品工業. 18:105-108.

21. 김동훈, 채현석, 장경만. 2004. 출하전 절식과 닭 고기 안전성 및 품질. 한국축산식품학회지. 24: 202-208.

22. 축산물등급판정소. 2003. 닭도체등급판정기준.

(접수일자 : 2008. 4. 28. / 수정일자 : 2008. 6. 4. /

채택일자 : 2008. 6. 18) 